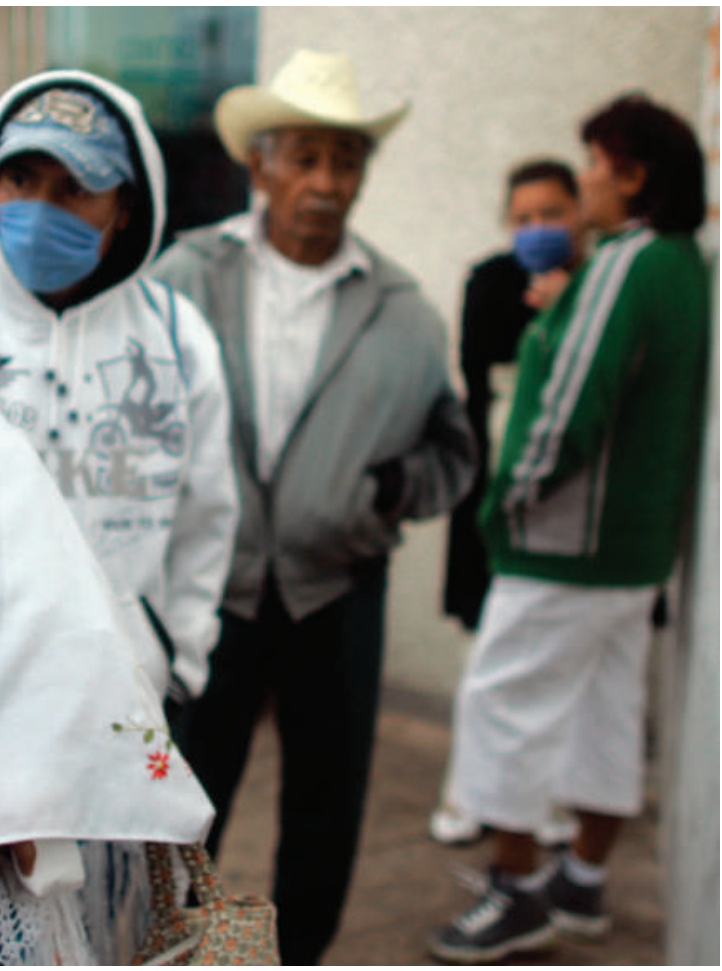

speed and scale of the response to the swine flu outbreak since it was formally identified last week, even though Mexican and international disease surveillance systems failed to pick it up promptly at the start. Several scientists speculate that the initial cases were months ago and perhaps outside Mexico. Ambitious WHO plans to quickly detect and extinguish an emerging pandemic before it grew, by distributing flu drugs, were thus not useful.

But once the virus was officially announced, governments have swung into action. The United States, for instance, has released onequarter of its 50 million stockpiled doses of oseltamivir and zanamivir for treatment in the affected states. The international response is being largely attributed to the amount of pandemic planning undertaken since the threat of a $\mathrm{H} 5 \mathrm{~N} 1$ pandemic emerged. Gene sequences of the virus samples, for instance, have been promptly shared on the Global Initiative on Sharing Avian Influenza Data (GISAID) database. Sequence information can have practical significance - for example, in designing PCR primers, to make rapid diagnosis tests that broaden and speed up surveillance.

Many virologists think they are in for the long haul. "Will this fizzle out? It doesn't look like it to me," says McCauley. "For me this is the time to start deploying national pandemic plans. We need to act now."

Declan Butler

For Nature's coverage of the swine flu outbreak, see www.nature.com/swineflu.

\title{
California in clean-fuel drive
}

The state of California has adopted regulations to curb greenhouse-gas emissions from transportation fuels, codifying evidence that biofuels are significantly dirtier than they were once thought to be.

The California Air Resources Board approved its 'low-carbon fuel standard' on 23 April, requiring fuel providers to cut the greenhouse-gas emissions from fuels by $10 \%$ by 2020 , compared with 2010 levels. The rule would also accomplish $10 \%$ of California's requirement to reduce emissions to 1990 levels by 2020, part of a broader plan to cut emissions by $80 \%$ by mid-century.

"We really think this is the future of fuels policy globally," says Anthony Eggert, a science adviser to the board. He says the policy should send a signal to the private sector and "drive clean transportation fuels and infrastructure into the market".

The regulation includes greenhousegas-emissions calculations for the life cycle of all fuels. To meet the requirement, refiners and importers would have to improve their production methods or mix and match the fuels that they sell. If they beat the standard, they can sell credits for their unused emissions to someone else.

Despite intense opposition from the US corn (maize) ethanol industry, the rule takes into account agricultural expansion abroad caused by rising grain prices as food crops are diverted for biofuels. This 'indirect' effect boosts the estimated emissions for various categories of corn ethanol by $50 \%$ or more, meaning that ethanol often results in higher greenhouse-gas emissions than gasoline.

Matt Hartwig, a spokesman for the Renewable Fuels Association in Washington DC, questions the science behind indirect emissions and says California has vastly overstated the problem. Many researchers, however, think there is enough evidence to move forwards now and re-evaluate as the science improves.

Dan Kammen, an energy researcher at the University of California, Berkeley, says California's calculation for indirect emissions is "reasonably consistent" with his team's work. "The science is new and evolving," he says, "but the low-carbon fuel standard is exactly the right approach."

The US Environmental Protection Agency is reviewing its own ruling that will establish greenhouse-gas criteria under the national biofuels mandate. European regulators are also looking into indirect emissions, but are not expected to make a determination until next year.

Tim Searchinger, an environmental researcher at Princeton University in New Jersey, identified the indirect effect in 2008 (T. Searchinger et al. Science 319, 1238-1240; 2008). He says California was conservative in its calculation of indirect emissions. His work suggests that corn ethanol could double emissions compared with gasoline over 30 years.

But one of the reasons for this difference, he says, is because California assumes that half of the food crops that are redirected towards energy will not be replaced because of rising prices, which he says translates into hunger in poorer countries. "Even though it's a best-case scenario for corn ethanol, the impact is still significant," Searchinger says. "Corn ethanol basically has no benefit, and it causes hunger."

Brazilian sugarcane ethanol, despite having an even higher indirect effect and being transported abroad, still performs better than any other biofuel. The California regulation does not yet include specific numbers for biodiesel, although the indirect impact could be even higher because of massive
expanding palm-oil emissions from expanding palm-oil
plantations, particularly in Indonesia. plantations, particularly in Indonesia.
The California regulation also covers fuels produced from the Canadian tar sands, which produce more emissions than conventional oil because of the energyintensive extraction process. The lowcarbon fuel standard could also prove a barrier to coal-based fuels, while providing a boost to vehicles powered by natural gas and electricity. Jeff Tollefson 